\title{
A New Tunnel Effect? The Impact of Stress on Vote Choice
}

\author{
Jérôme Couture ${ }^{1}$ and Sandra Breux ${ }^{2 *}$ \\ ${ }^{1}$ Political Science, Laval University, Quebec, QC, Canada, ${ }^{2}$ Institut National de la Recherche Scientifique, Montréal, QC, Canada
}

The literature shows a link between stress and voter turnout, but does stress influence vote choice as well? What would explain such a relationship? Using a survey of Quebec (Canada) voters conducted during the 2017 municipal election $(n=1,130)$, we show that 1) there is a relationship between stress and vote choice, and 2) voters who consider road congestion to be an important issue and who report being stressed tend to vote for the party that has taken a stand in favor of highway projects and against public transit. While many studies show an association between road congestion and the psychological health of individuals, our research invites us to consider the political impacts of such a relationship.

Keywords: stress, voter choice, issue ownership theory, self-rated mental health, urban mobility

\section{HIGHLIGHTS}

OPEN ACCESS

Edited by:

Hanna Wass,

University of Helsinki, Finland

Reviewed by: Lauri Rapeli, Abo Akademi University, Finland Maria Solevid, University of Gothenburg, Sweden

*Correspondence: Sandra Breux sandra.breux@ucs.inrs.ca

Specialty section: This article was submitted to Elections and Representation, a section of the journal Frontiers in Political Science

Received: 30 July 2020 Accepted: 27 January 2021 Published: 11 March 2021

Citation: Couture $J$ and Breux S (2021) A New Tunnel Effect? The Impact of Stress on Vote Choice.

Front. Polit. Sci. 3:589548. doi: 10.3389/fpos.2021.589548
Stress level influences vote choice. Respondents who were more stressed tended to vote for a new procar party rather than traditional parties. The strength of the relationship between stress and vote choice varies depended on the importance respondents placed on the issues of traffic and congestion and public transit. The relationship between stress and vote choice is not explained by dissatisfaction with the incumbent or self-rated mental health. Poor self-rated mental health favors voting for parties located more to the left.

\section{INTRODUCTION}

Studies show that urban mobility issues can influence stress (Beland and Brent 2018) and that stress is linked to mental health and voter turnout (Thoits, 2013; Hassell and Settle 2017). Moreover, mental health is associated with political ideology, electoral participation and vote choice, while dissatisfaction and anxiety influence the attention voters give to political issues (Bernardi, 2020b). In addition, the importance of an issue and its ownership by a political party can influence vote choice (Petrocik 1996). However, two questions remain: First, to what extent does stress influence vote choice? Second, can an every-day issue such as transportation have an effect on this relationship?

To answer these two questions, we begin by addressing the links between stress and vote choice. We will then present our methodological approach, which was based on a survey of voters before and after the 2017 municipal election in Quebec City, Canada $(n=1,130)$. We will then present our results. We will show that there is a link between stress and vote choice. Respondents who were more stressed tended to vote for a new pro-car party rather than the traditional parties. The relationship between stress and vote choice varies depending on the importance respondents placed on the issues of traffic congestion and public transit. The relationship between stress and vote choice is not affected by ideology or self-rated mental health. Until now, studies have mainly focused on the importance of ideology in the relationship between health and vote choice. 
However, the effect of stress goes beyond the left-right divide and invites us to reflect on both the importance of this phenomenon to voting and the structuring of the political scene.

\section{LITERATURE REVIEW}

\section{Stress and Vote Choice}

There is a large body of literature that has established a clear link between an individual's health status and electoral participation (Burden et al., 2017; Mattila et al., 2018; Gagné et al., 2020). Some work has focused more specifically on the link between mental health and voting (Johnson 2017; Bernardi 2020a; Bernardi and Johns 2020). For example, Denny and Doyle (2007) showed that poor mental health negatively influences voter turnout, while Sund et al. (2017) showed that neuro-degenerative diseases, alcoholism and mental health issues likewise tend to reduce electoral participation. Stress has received special attention in these analyses (Booth and Welch 1978), based on the idea that people who experience high levels of stress in their daily lives are more likely to be the same people who do not participate regularly in elections (Hassell and Settle 2017). Mental health is generally linked to the notion of well-being, and so stress is likely to affect the quality of mental health (Thoits 2013). However, we don't know if stress is also likely to influence vote choice.

Some studies have also shown the existence of a link between political ideology and health (Subramanian and Perkins 2010) and have argued that ideology mediates the relationship between health and vote choice (Rapeli et al., 2020). Some analyses thus show that healthy people are more to the right of the political spectrum while those with poorer health tend to be more to the left and vote accordingly. Yet such studies are unable to explain if a common health issue such as stress plays a role in this relationship.

In Affective Intelligence and Political Judgement, Marcus et al. (2000) argue that political choices are not motivated solely by habit but also by emotions such as anxiety and dissatisfaction, which may promote a change in party preference. As Marcus and MacKuen point out: "In the absence of anxiety, voters safely rely on preexisting partisan dispositions and the greater enthusiasm generated by the favored candidate; however, when disturbed by their emotional signals, voters pay more attention to the issues and no longer defer to established dispositions. Rather than being antagonistic or detrimental to citizenship, emotion enhances the ability of voters to perform their citizenly duties" (Marcus and MacKuen 1993, 681). In addition, Affective Intelligence theory suggests that when anxiety increases, the voter bases his or her choice more on the personal qualities of the candidates and their positions on certain issues: "[...] anxious voters would experience a heightened motivation to learn, to gather contemporary information, to know more about the issues and where the candidates stand on the issues (Marcus et al., 2000, 61). It is possible that stress operates similarly.

The Yerkes and Dodson (1908) law states that there is a relationship between stress and the performance of a task, and that this relationship depends on the degree of familiarity with the task to be performed and its complexity. In other words, there is an optimal level of stress that favors certain behaviors, notably a change in behavior. Both excess stress and lack of stress reduce performance in the accomplishment of a task (Gollust and Rahn 2015). This reasoning can be applied to voting, widely understood to be a habit, which some political scientists refer to as "consuetude" (Green and Shachar 2000). As Cravens (2020), points out, "[...] people who repeatedly vote appear to do so partly because voting is more automatic and effortless for them and because failing to vote has consequences for their self-conceptions." Gomez (2013) also shows that a process of habituation could partly explain vote choice.

The presence of a certain level of stress could, however, undermine this propensity to vote routinely and induce a change in vote choice and even favor support for new political parties. In that case, voters who are more (but not excessively) stressed would be more likely to be influenced by the political context of the election (Cravens 2020). The importance of the political context is therefore not to be neglected, since the emergence of new political actors is more likely to occur in the presence of dissatisfaction among the electorate (Pinard 1973).

It should also be mentioned that the majority of studies linking health and voting behavior are national in scope. In the case of mental health, however, Couture and Breux (2017) showed the influence of mental health on participation at the municipal level. In addition, Hassell and Settle (2017) showed that stress affects voter turnout at the municipal level. This invites further reflection because the political issues raised in municipal elections, in the United States and Canada more specifically, generally affect people's daily lives. Some of these issues can therefore be a source of stress for citizens.

For example, traffic congestion is an issue facing many cities today and is likely to affect people's daily life. Using data from the Canadian General Social Survey, Turcotte (2011) highlights the link between stress and traffic congestion experienced by motorists and the time spent commuting or otherwise in transit. Numerous studies show the negative consequences of road and vehicle congestion on the mental health of individuals, particularly in relation to the level of stress generated (Beland and Brent 2018) and the loss of quality of life (Anderson et al., 2016). As stated by Gee and Takeuchi (2004), "traffic stress may represent an important factor that influences the well-being of urban populations" (see also Song et al., 2007).

Traffic congestion also figures in the political arena and is often taken up by political parties that can be described as pro-car (Rosen 2002). The dominance of the automobile, particularly in North America, and the fact that urban planning has often been designed with this mode of transport in mind (Saidla et al., 2017), makes traffic and road congestion as well as modes of travel a politically divisive issue. The way in which a political party takes ownership of this issue, as per the issue ownership theory (Petrocik 1996), and the importance of the issue to voters are then likely to influence the results of an election (Bélanger and Meguid 2008; Lefevere et al., 2019). 
Based on these findings, we derive two hypotheses. First, we expect that a higher level of stress will be associated with a higher propensity to vote for the new pro-car party. The arrival of a new party on the political scene is likely to change voting habits, particularly when voters are stressed. In line with the affective intelligence theory, we expect that higher levels of stress will lead voters to be more attentive to the issues raised by the new political party, in turn inducing them to change their vote in favor of the party.

H1. Higher levels of stress are associated with greater support for the new pro-car party.

According to the Yerkes-Dodson law, the relationship could instead be curvilinear (i.e., the propensity to support the pro-car party increases as stress goes up but then declines for voters who are extremely stressed). We will also test this possibility.

Second, we expect the relationship between stress and political choice to be moderated by the importance given to transportation issues. The relationship between stress and vote choice will likely be stronger for voters who place greater importance on the issue of traffic and congestion. Ownership of the traffic and congestion issue belongs to the new pro-car party, while the transit public issue is divided between the other two parties. Voters who are more stressed and therefore more attentive to the issues raised by the election campaign are expected to be more likely to vote for the new pro-car party if they consider the issue of traffic and congestion to be more important than that of public transit.

$\mathrm{H} 2$. The relationship between stress and vote choice is stronger among those who place greater importance on the issue of traffic and congestion than on the issue of public transit.

\section{METHODOLOGY}

To answer our questions, we use data from the Canada Municipal Election Study (CMES). CMES conducted a survey on municipal elections in 2017 and 2018 in eight Canadian cities, including Quebec City. The survey is based on the federal and provincial election studies but also includes specific questions at the municipal level. The Quebec City survey was conducted online in two phases. First, a pre-election questionnaire was administered in the weeks leading up to election day (November 5, 2017), reaching 1,713 respondents of whom 1,356 participated in the post-election survey conducted in the weeks following the election. In all, 1,130 respondents provided responses to the questions used in our analysis. Respondents were recruited by telephone via random digit dialing (RDD). They answered a question over the phone and then received a link to complete the questionnaire. This ensured that the sample was random and as representative as possible. This was complemented, for cost and time reasons, by respondents from an existing panel.

This election involved three main parties [effective number of party calculation: 2.48 (Laakso and Taagepera 1979)]. All three parties took a clear position on the issue of transportation. Indeed, it was an issue that distinguished the political parties particularly well. According to the respondents, the issue of traffic and road congestion (8.3/10) was the main issue of the election campaign, closely followed by the issue of public transit (7.2/10). Équipe Labeaume, the party of the mayor, was in favor of public transit. Démocratie Québec, the official opposition, was also in favor of public transit. Québec 21, a new political party, on the other hand, was in favor of a new highway project and opposed to public transit projects proposed by the other two parties. This party was described as "pro-car" by local newspapers (Bourque 2017). Seventy-seven percent of CMES respondents who supported Québec 21 attached more importance to traffic and congestion than to public transit, compared to 41 percent for Équipe Labeaume and 16 percent for Démocratie Québec. Following the 2017 election, the incumbent mayor was reelected and the new pro-car party became the official opposition. It should be noted that municipal political parties in Quebec have no ties with the provincial and federal parties. From an ideological point of view, respondents positioned the incumbent party, Équipe Labeaume, on the center-right (5.5/10), Démocratie Québec on the left (3.9/10) and Québec 21, the procar party, on the right (7.0/10) (Breux et al., 2020 forthcoming).

Our dependent variable is vote choice measured by a binary variable. We will compare respondents who voted for the new pro-car party (Québec 21) to those who voted for the pro public transit parties (Équipe Labeaume and Démocratie Québec). The analysis will therefore be based on linear probability models, i.e., OLS with binary dependent variables. Linear probability models have the advantage of being easy to interpret and the results are very similar when binary logistic regression is used instead. In contrast to the latter, they also allow for a comparison of effects across nested models (Karlson et al., 2012).

Our main independent variable is stress, which was measured by responses to the following question: Thinking of the amount of stress in your life, would you say that on most days you feel ... ? The respondent had the following response choices: "not at all stressed," "not very stressed," "quite a bit stressed" and "extremely stressed." The results were analyzed using dummy variables with the reference category for interpreting the results being "not at all stressed". Dummy variables are used to test the possibility of a curvilinear relationship.

Our main moderating factor is the importance of transportation issues. As shown, transportation issues were considered to be the most important issues for voters, and whether the respondent voted for one or the other of the parties varied greatly depending on the importance given to these issues. We created a dummy variable coded one for the respondents who gave more importance to the issue of traffic and congestion than to the issue of public transit and zero otherwise.

Our main alternative predictors of vote choice are age, gender, education, home ownership, and whether or not the respondent lives in the suburbs. Since the 2001 amalgamation, the Quebec City electoral districts have followed the division between downtown and the merged suburban cities, which makes it possible to identify the respondents' place of residence. These are the key socio-economic factors to consider in explaining vote choice at the municipal level in Canada (McGregor and Spicer 2016). These same factors are also important sources of variation in people's health (Commission on Social Determinants of Health, World Health Organization 2019). For example, 46.8\% of CMES respondents between the ages of 18 and 34 years said they were quite or extremely stressed, compared to 34.7 percent among 35-64 years 
TABLE 1 | Stress and Vote Choice

\begin{tabular}{|c|c|c|c|}
\hline $\begin{array}{l}\text { Linear probability model } \\
\text { (OLS with Robust } \\
\text { SE) }\end{array}$ & Model 1 & Model 2 & Model 3 \\
\hline $\begin{array}{l}\text { Dependent variable: } 1 \text { = vote for the new "pro- car" party } 0=\text { Vote } \\
\text { for "pro public transit" parties } \\
\text { Not very stressful }\end{array}$ & $\begin{array}{l}\text { Socioeconomic } \\
\text { factors } \\
\mathbf{0 . 0 7}(\mathbf{0 . 0 4 )}\end{array}$ & $\begin{array}{l}\text { Socioeconomic factors }+ \text { Self-rated } \\
\text { mental health } \\
\mathbf{0 . 0 8}^{\star}(\mathbf{0 . 0 4 )}\end{array}$ & $\begin{array}{c}\text { Socioeconomic factors }+ \text { Satisfaction } \\
\text { with incumbent } \\
0.02(0.03)\end{array}$ \\
\hline Quite a bit stressful & $0.15 * \star *(0.04)$ & $0.18^{\star \star \star}(0.04)$ & $0.09^{\star *}(0.03)$ \\
\hline Extremely stressful & $0.21^{*}(0.09)$ & $0.24^{\star \star}(0.09)$ & $0.17^{*}(0.08)$ \\
\hline Age & $\begin{array}{c}-0.000001 \\
(0.00001)\end{array}$ & $-0.0000004(0.00001)$ & $-0.000008(0.000009)$ \\
\hline Male & $0.13^{\star \star \star}(0.03)$ & $0.13^{\star \star \star}(0.03)$ & $0.09^{\star \star \star}(-0.02)$ \\
\hline Home owner & $0.04(0.03)$ & $0.03(0.03)$ & $-0.01(0.02)$ \\
\hline High school or less & $0.06(0.05)$ & $0.05(0.05)$ & $0.05(0.03)$ \\
\hline University degree & -0.09 ** $(0.03)$ & $-0.09^{\star \star}(0.03)$ & $-0.08^{\star \star}(0.02)$ \\
\hline Suburb & $0.20^{\star \star \star}(0.03)$ & $0.20^{\star \star \star}(0.03)$ & $0.22^{\star \star \star}(0.02)$ \\
\hline Self-rated mental health & - & $-0.05^{\star \star}(0.02)$ & - \\
\hline Satisfaction with incumbent performance & - & - & $-0.52^{\star \star \star}(0.02)$ \\
\hline (n) & $(1,130)$ & $(1,130)$ & $(1,126)$ \\
\hline $\mathrm{R} 2$ & 0.08 & 0.09 & 0.37 \\
\hline
\end{tabular}

${ }^{*} p<0.05 ;{ }^{* *} p<0.01 ;{ }^{* *} p<0.001$.

old and only $21.1 \%$ among those aged 65 and over. At the same time, the older a person is, the more likely he or she is to keep voting for the same party out of habit (Converse, 1976). Accordingly, older respondents may be less likely to vote for the new pro-car party. As a result, any association between stress and vote choice could be spurious, simply reflecting the fact that both stress and vote choice share a common cause (namely, age).

The potential confounding factors considered are self-rated mental health and (dis)satisfaction with the performance of the incumbent mayor, all of which are theoretically related to both stress and voting (see above, in particular the paragraph on the theory of affective intelligence). The descriptive analysis, the correlation matrix and the description of the different variables are all available in the Supplementary Material.

\section{RESULTS}

Models 1 to 3 in Table 1 test hypothesis 1, in other words, whether stress is associated with vote choice. Model 1 tests the hypothesis by controlling only for socio-economic factors. It shows that stress has a statistically significant effect on voting. Specifically, respondents who reported being "quite a bit stressed" or "extremely stressed" were more likely to vote for the new pro-car party. The probability of voting for the pro-car party is $15 \%$ points higher for respondents who reported being "quite a bit stressed" and $21 \%$ points higher for those who reported being "extremely stressed" compared to the reference category of "not at all stressed." These relationships are statistically significant at the 0.001 and 0.05 levels, respectively. However, the difference between respondents who reported being "not very stressed" and those who reported being "not at all stressed" is not significant.

Model 2 tests the effect of self-rated mental health on the relationship between stress and vote choice. The previous literature has observed a link between stress and mental health as well as between mental health and vote choice. However, Model 2 shows that self-rated mental health does not explain the relationship between stress and vote choice. Indeed, the addition of this variable to Model 2 reveals that being "not very stressed" also has a significant effect $(p<0.05)$ on vote choice. At the same time, the results do show a significant relationship between self-rated mental health and vote choice. More specifically, the more fragile a respondent considers his or her mental health to be, the less likely he or she was to vote for the new pro-car party. This relationship is significant at the 0.05 level. The probability of voting for the pro-car party is eight percentage points lower for these respondents.

Model 3 tests the effect of (dis)satisfaction with the performance of the incumbent mayor on the relationship between stress and vote choice. While the results show that support for the new pro-car party is highly correlated with dissatisfaction with the incumbent, the introduction of this variable has only a small effect on the relationship between stress and vote choice, which remains significant as in Model 1.

Table 2 tests Hypothesis 2, in other words, whether the importance of transportation issues moderates the relationship between stress and vote choice. Model 4 introduces an interaction between stress and the importance of the transportation issue. The results show the presence of a significant interaction effect for those who are quite a bit stressed and who consider the traffic and congestion issue more important than the public transit one. This result can be interpreted as a partial confirmation of hypothesis 2 . It is possible to visualize this relationship in Figure $\mathbf{1}$.

Figure 1 shows that the predicted vote for the new pro car party is higher among those who place greater importance on the issue of traffic and congestion than on the issue of public transit. The probability of voting for the pro-car party is much higher for respondents who consider the issue of traffic and congestion to be more important than public transit and the effect of stress on their support also increases more rapidly among these same respondents. More importantly, respondents who reported being "quite a bit stressed" are significantly more likely $(0.55)$ to vote for the pro-car party than those "not at all stressed" (0.35), but only if they attach 
TABLE 2 | Interaction effect of transport issues and stress on vote choice

Model 4

Dependent variable: 1 = vote for the new "pro-car" party

$0=$ Vote for "pro public transit" parties

Not very stressful

Quite a bit stressful

Extremely stressful

Traffic and congestion more important than Public transit

Not very stressful $X$ Traffic and congestion more important than Public transit

Quite a bit stressful X Traffic and congestion more important than Public transit

Extremely stressed $X$ Traffic and congestion more important than Public transit

Age

Male

Home owner

High school or less

University degree

Suburb

(n)

$\mathrm{R} 2$

${ }^{*} \mathrm{p}<0.05 ;{ }^{* *} \mathrm{p}<0.01 ;{ }^{* * *} \mathrm{p}<0.001$.
Interaction stress \# Transport issues

$$
\begin{gathered}
\mathbf{0 . 0 2}(0.04) \\
\mathbf{0 . 0 4}(0.05) \\
\mathbf{0 . 2 4} \text { * }(\mathbf{0 . 1 1}) \\
\mathbf{0 . 1 7}(\mathbf{0 . 1 5}) \\
\mathbf{0 . 1 0}(\mathbf{0 . 0 8}) \\
\mathbf{0 . 2 0} \text { * (0.09)} \\
\mathbf{0 . 1 4}(\mathbf{0 . 1 7}) \\
-0.0000003(0.000009) \\
0.11^{\star \star \star}(0.03) \\
0.03(0.03) \\
0.03(0.04) \\
-0.05(0.03) \\
0.10^{\star \star \star}(0.03) \\
(1,127) \\
0.23
\end{gathered}
$$

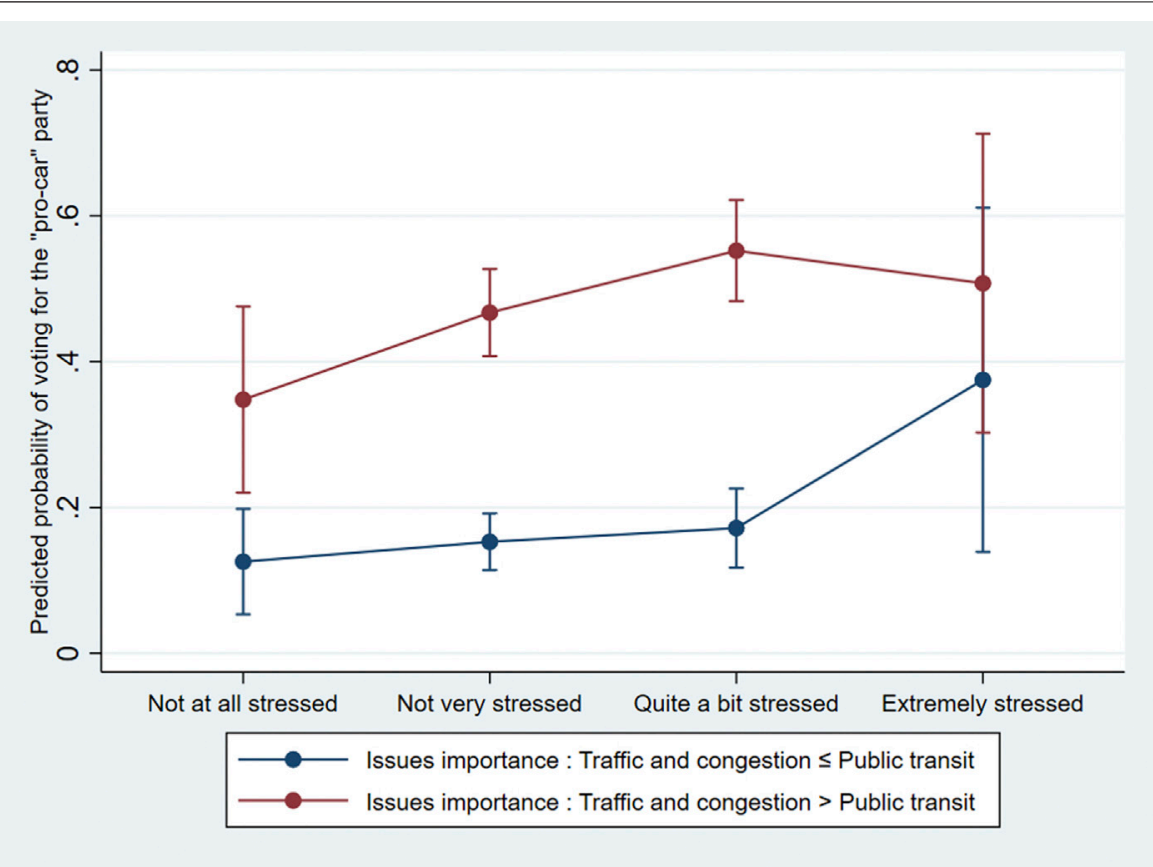

FIGURE 1 | The interaction between stress and the importance of transport issues (with 95\% confidence intervals).

greater importance to traffic and congestion than to public transit. This is a significant difference of $20 \%$ points. The relationship is curvilinear for those who consider the issue of traffic and congestion to be more important. With the exception of those who reported being extremely stressed, none of the stress categories have a statistically significant effect on vote choice for respondents who place more importance on the issue of public transit than on the issue of traffic and congestion. However, respondents who reported being extremely stressed were significantly more likely to vote for the pro-car party. Indeed, they did not differ statistically in their probability of voting for the pro-car party compared to their counterparts who consider this issue to be more important than public transit. Thus Hypothesis 2 is only partially confirmed.

\section{CONCLUDING DISCUSSION}

Our research shows that there is a link between stress and vote choice. Respondents who were more stressed were more likely to support a new pro-car party. Our results are also in line with the affective intelligence theory developed by Marcus et al. (2000), which holds that a feeling of dissatisfaction favors a vote for a new 
party, which, in the framework of our study, invites us to reflect on the strategies of political parties. We also noticed that, contrary to the Yerkes-Dodson Law, the relationship between stress and vote choice stress is only curvilinear for those who are more concerned about traffic and congestion than about public transit.

However, our investigation is not able to establish a direct link between stress and traffic and road congestion: we don't know the extent to which the stress that respondents experienced is due to traffic and road congestion. The survey did not contain a specific question on their experiences, nor were their car ownership or transportation habits documented. Nevertheless, the set of alternative predictors tested shows that it is likely that stress is related-at least in part and in the specific context of this election-to experiencing traffic and road congestion. This could include both those who have experienced traffic and congestion in their cars and those who have experienced it as a passenger on a public transit system.

The mechanism linking stress to a public issue that is likely to influence vote choice remains to be detailed. In the case presented, people who reported feeling stressed were more likely to vote for the party that is on the right side of the political spectrum and that has a specific transportation project that differs from the other parties. This result contradicts other studies that show that people whose health is deteriorating or otherwise impaired tend to vote more to the left (Rapeli et al., 2020). That hypothesis is confirmed in our results for mental health, but not for stress. Respondents judging their mental health to be more fragile voted for the pro-public transit parties located more to the left of the ideological spectrum. In this specific case, stress, unlike other health variables, is related to voting for a right-wing party. These results suggest that stress and mental health may not be linked by the same mechanisms with voting. Stress invites us to consider the influence of the political context and more particularly of certain issues on the relationship with vote choice. These results also raise questions. Can these results be explained by the presence of a new party and the fact that it is clearly positioned on the right side of the political spectrum? Or can these results be explained by the presence of three conditions: the presence of a new party, its position on the right and the importance of the traffic issue?

Moreover, the fact that stressed people have chosen to vote for a new pro-car party raises questions as to how political parties appropriate and communicate an issue during an election campaign. For example, can the tendency, in this case, to vote for a new highway project, be attributed to the fact that people think-as the Canadian General Social Survey (Turcotte 2011) pointed out-that public transit trips take longer and that this loss of time, which is likewise a source of stress, would hence not solve the problem? Or do people think that the public transit projects defended by the other two parties were too unconvincing and that, as a result, these parties failed to take ownership of the campaign issue?

We also point to an analogy to the tunnel effect described by Hirschman and Rothschild (1973). The tunnel effect refers to a decrease in a car driver's field of vision as their speed increases, and hence to the limitations of information processing while driving a car. Hirschman and Rothschild applied this metaphor to the initial tolerance of increased inequality resulting from uneven economic growth processes. We believe that the tunnel effect may likewise be applied to our results. Indeed, if stress favors the voter's attention to an issue raised by the campaign, as supported by the theory of affective intelligence, stress could push aside other issues in the voter's decisionmaking process and accentuate the desire to reap short-term benefits. This decrease in the voter's field of vision may result in some perverse effects and even a vicious circle. It is not unrelated to the idea of scarcity, defined as a mindset that changes the way we think, detailled by Mullainathan and Shafir (2014), "Scarcity causes us to tunnel: to focus single-mindedly on managing the scarcity at hand [... S Scarcity focuses us on what seems, at that moment to matter most [...] scarcity leads us to tunnel and neglect other, possibly more important, things". For example, stress seems to have encouraged voting for the party that promised to solve the problem of traffic congestion by building new highways. Voters may anticipate that they will have less stress in getting to places if there are more highways, as these would make it easier for others to get around. In the long term, however, a vicious circle emerges: the creation of new roads attracts more vehicles and thus creates more congestion, which is known as the fundamental law of road congestion (Down 1962).

Our research suggests that there are still gray areas to explore in both political science and health regarding the relationship between health and vote choice. From a health perspective, stress (and the more specific mechanisms that are likely to come into play, and the extent to which they come into play) as a factor in mental health remains to be explored in greater depth in order-among other things-to better grasp the consequences for voting (Couture and Breux 2017; Ojeda and Slaughter 2019). From a political science point of view, the specificity of the municipal scene also requires further analysis to understand how this is likely to influence vote choice, particularly in view of the stress that voters may experience.

\section{DATA AVAILABILITY STATEMENT}

The raw data supporting the conclusions of this article will be made available by the authors, without undue reservation.

\section{ETHICS STATEMENT}

The studies involving human participants were reviewed and approved by Research Ethics Board of Ryerson University. The patients/participants provided their written informed consent to participate in this study.

\section{AUTHOR CONTRIBUTIONS}

JC and SB discussed the framework of this article together when they received the call for proposals. JC then took responsibility for the statistical processing and the description of the results and $\mathrm{SB}$ for writing the rationale. The two authors then discussed the results and sent one another several versions until bringing the paper to completion. JC: $55 \%$; SB: $45 \%$.

\section{SUPPLEMENTARY MATERIAL}

The Supplementary Material for this article can be found online at: https://www.frontiersin.org/articles/10.3389/fpos.2021.589548/ full\#supplementary-material. 


\section{REFERENCES}

Anderson, M. L., Lu, F., Zhang, Y., Yang, J., and Qin, P. (2016). Superstitions, street traffic, and subjective well-being. J. Public Econ. 142, 1-10. doi:10.1016/j. jpubeco.2016.07.005

Beland, L.-P., and Brent, A. (2018). Traffic and crime. J. Public Econ. 160, 96-116. doi:10.1016/j.jpubeco.2018.03.002

Bélanger, É., and Meguid, B. (2008). Issue salience, issue ownership, and issuebased vote choice. Elect. Stud. 27 (3), 477-491. doi:10.1016/j.electstud.2008. 01.001

Bernardi, L. (2020a). Depression and political predispositions: almost blue? Party Polit. 135406882093039. doi:10.1177/1354068820930391

Bernardi, L. (2020b). Mental health and political representation : a roadmap. Front. Polit. Sci. 2, 587588. doi:10.3389/fpos.2020.587588

Bernardi, L., and Johns, R. (2020). Depression and attitudes to change in referendums: the case of Brexit. Eur. J. Polit. Res. 12398, 1475-6765. doi:10.1111/1475-6765.12398

Booth, A., and Welch, S. (1978). Stress, health, and political participation. Soc. Biol. 25 (2), 102-114. doi:10.1080/19485565.1978.9988328

Bourque, F. (2017). La «droite-Auto» change La Donne. Le Soleil. Available at: https:/www.lesoleil.com/chroniques/francois-bourque/la-droite-auto-changela-donne-9bd8d465b9f23ad4c170cca0b449a760 (Accessed May 16, 2017).

Breux, S., Couture, J., and Mévellec, A. (Forthcoming 2020). "Does the left-right axis matter at the municipal level?," in A tale of two cities. Editor M. Mc Gregor (Toronto, CA: University of Toronto Press).

Burden, B. C., Fletcher, J. M., Herd, P., Jones, B. M., and Moynihan, D. P. (2017). How different forms of health matter to political participation. J. Polit. 79 (1), 166-178. doi:10.1086/687536

Commission on Social Determinants of Health, World Health Organization (2019). Combler Le Fossé En Une Génération. Instaurer l'équité En Santé En Agissant Sur Les Déterminants Sociaux de La Santé. Available at: https:// apps.who.int/iris/bitstream/handle/10665/69831/WHO_IER_CSDH_08.1_fre. pdf;jsessionid=6958EA7D41E1E329B6082BA1D8DB445D? sequence=1 (Accessed July, 27 2020).

Converse, P. E. (1976). The dynamics of party support: cohort-analyzing party identification. Beverly Hills, Calif: sage library of social research. Am. Polit. Sci. Rev. 72, 1403-1404. doi:10.2307/1954573

Couture, J., and Breux, S. (2017). The differentiated effects of health on political participation. Eur. J. Public Health 27, 599-604. doi:10.1093/eurpub/ckw245

Cravens, M. D. (2020). Measuring the strength of voter turnout habits. Elect. Stud. 64, 102117. doi:10.1016/j.electstud.2020.102117

Denny, K. J., and Doyle, O. M. (2007). “...Take up Thy Bed, and Vote” measuring the relationship between voting behaviour and indicators of health. Eur. J. Public Health 17 (4), 400-401. doi:10.1093/eurpub/ckm002

Downs, A. (1962). The law of peak-hour expressway congestion. Traffic Quart. 16 (3), 393-409.

Gagné, T., Schoon, I., and Sacker, A. (2020). Health and voting over the course of adulthood: evidence from two British birth cohorts. SSM-Popul. Health 10, 100531. doi:10.1016/j.ssmph.2019.100531

Gee, G. C., and Takeuchi, D. T. (2004). Traffic stress, vehicular burden and wellbeing: a multilevel analysis. Soc. Sci. Med. 59 (2), 405-414. doi:10.1016/j. socscimed.2003.10.027

Gollust, S. E., and Rahn, W. M. (2015). The bodies politic: chronic health conditions and voter turnout in the 2008 election. J. Health Polit. Policy 40 (6), 1115-1155. doi:10.1215/03616878-3424450

Gomez, R. (2013). All that you can(not) leave behind: habituation and vote loyalty in Netherlands. J. Elect. Public Opin. Parties 23 (2), 134-153. doi:10.1080/ 17457289.2013.776056

Green, D. P., and Shachar, R. (2000). Habit formation and political behaviour: evidence of consuetude in voter turnout. Br. J. Polit. Sci. 30 (4), 561-573.

Hassell, H. J. G., and Settle, J. E. (2017). The differential effects of stress on voter turnout: differential effects of stress on voter turnout. Polit. Psychol. 38 (3), 533-550. doi:10.1111/pops.12344

Hirschman, A. O., and Rothschild, M. (1973). The changing tolerance for income inequality in the course of economic development. Q. J. Econ. 87 (4), 544-566. doi:10.2307/1882024

Johnson, A. (2017). Mental health and voter turnout: a study of Georgia counties. Georg. J. Public Pol. 3 (1), 1-18.
Karlson, K., Holm, A., and Green, R. (2012). Comparing regression coefficients between same-sample nested logit and probit: a new method. Sociol. Methodol. 42, 286-313. doi:10.1177/0081175012444861

Laakso, M., and Taagepera, R. (1979). "Effective” number of parties: a measure with application to West Europe. Comp. Polit. Stud. 12 (1), 3-27. doi:10.1177/ 001041407901200101

Lefevere, J., Sevenans, J., Walgrave, S., and Lesschaeve, C. (2019). Issue reframing by parties: the effect of issue salience and ownership. Party Polit. 25 (4), 507-519. doi:10.1177/1354068817736755

Marcus, G., and MacKuen, M. (1993). Anxiety, enthusiasm and the vote: the emotional underpinnings of learning and involvement during presidential campaigns. Am. Polit. Sci. Rev. 87 (3), 672-685. doi:10.2307/2938743

Marcus, G., Neuman, R., and MacKuen, M. (2000). Affective Intelligence and political judgment. Chicago, Illinois: University of Chicago Press, 199.

Mattila, M., Wass, H., Lahtinen, H., and Martikainen, P. (2018). Sick leave from work and the voting booth? a register-based study on health and turnout. Acta Polit. 53 (3), 429-447. doi:10.1057/s41269-017-0062-0

McGregor, M., and Spicer, Z. (2016). The Canadian homevoter: property values and municipal politics in Canada. J. Urban Aff. 38 (1), 123-139. doi:10.1111/ juaf. 12178

Mullainathan, S., and Shafir, E. (2014). Scarcity: the new science of having less and how it defines our lives. 1st Edn. New York, NY: Picador/Henry Holt and Co, 304.

Ojeda, C., and Slaughter, C. M. (2019). Intersectionality, depression, and voter turnout. J. Health Polit. Policy 44 (3), 479-504. doi:10.1215/03616878-7367036

Petrocik, J. R. (1996). Issue ownership in presidential elections, with a 1980 case study. Am. J. Polit. Sci. 40 (3), 825. doi:10.2307/2111797

Pinard, M. (1973). Third parties in Canada revisited: a rejoinder and elaboration of the theory of one-party dominance. Can. J. Polit. Sci. 6 (3), 439-460. doi:10. 1017/S0008423900040026

Rapeli, L., Mattila, M., and Papageorgiou, A. (2020). Breaking a habit: the impact of health on turnout and party choice. Party Polit. 26 (2), 133-142. doi:10.1177/ 1354068817753060

Rosen, P. (2002). "Transport lessons from the fuel tax protests of 2000," in Pro-car or anti-car? "environment", "economy", and "liberty" in United Kingdom transport debates. Editors G. Lyons and K. Chatterjee. 1st Edn (London, United Kingdom: Routledge), 27-46.

Saidla, K., Préfontaine, A., Clavier, C., and Crespin, R. (2017). Le transport actif à Ottawa (Canada) face à des obstacles politiques tenaces. Lien Soc. Politiques 78 , 171-192. doi:10.7202/1039344ar

Song, Y., Gee, G. C., Fan, Y., and Takeuchi, D. T. (2007). Do physical neighborhood characteristics matter in predicting traffic stress and health outcomes? Trans. Res. F-Traf. 10 (2), 164-176. doi:10.1016/j.trf.2006.09.001

Subramanian, S. V., and Perkins, J. (2010). Are republicans healthier than democrats? Int. J. Epidemiol. 39, 930-935. doi:10.1093/ije/dyp152

Sund, R., Lahtinen, H., Wass, H., Mattila, M., and Martikainen, P. (2017). How voter turnout varies between different chronic conditions? a population-based register study. J. Epidemiol. Commun. H 71 (5), 475-479. doi:10.1136/jech2016-208314

Thoits, P. A. (2013). "Self, identity, stress, and mental health," in Handbook of the sociology of mental health. Editors C. S. Aneshensel, J. C. Phelan, and A. Bierman (Dordrecht, Netherlands: Springer), 357-377.

Turcotte, M. (2011). “Se rendre au travail: résultats de l'enquête sociale générale de 2010," in Composante du produit n 11-008-X. Tendances Sociales Canadiennes. Ottawa: Statistics Canada.

Yerkes, R. M., and Dodson, J. D. (1908). The relationship of strength of stimulus to rapidity of habit formation. J. Comp. Neurol. Psychol. 18, 459-482. doi:10.1002/ cne.920180503

Conflict of Interest: The authors declare that the research was conducted in the absence of any commercial or financial relationships that could be construed as a potential conflict of interest.

Copyright (c) 2021 Couture and Breux. This is an open-access article distributed under the terms of the Creative Commons Attribution License (CC BY). The use, distribution or reproduction in other forums is permitted, provided the original author(s) and the copyright owner(s) are credited and that the original publication in this journal is cited, in accordance with accepted academic practice. No use, distribution or reproduction is permitted which does not comply with these terms. 